\title{
SISTEM TANDA SEBAGAI CITRA : STUDI KASUS UNIVERSITAS TRISAKTI
}

\author{
Bambang Tri Wardoyo \\ FSRD Universitas Trisakti \\ bambangtri@gmail.com
}

\begin{abstract}
Abstrak
Tulisan ini adalah bedah buku berjudul Reading Images: The Grammar of Visual Design, karya Gunther Kress dan Theo van Leeuwen, terbit pertama kali pada tahun 1996. Untuk memudahkan pemahaman, dipakai sejumlah contoh sign system pada Universitas Trisakti, kampus A. Aturan (grammar) desain visual memainkan peran penting, sebagai bagian dari proses menghasilkan makna. Kress-Leeuwen berusaha menyediakan tata cara dalam membaca tanda-tanda yang menjadi kesepakatan (convention) di bidang semiotika visual. Tujuan buku ini adalah untuk menganalisa bagaimana semiotika dipakai untuk menghasilkan makna dan mengkaji citra masa kini (contemporary). Buku ini sangat sistematis dan komprehensif terhadap tata bahasa desain visual. Mencermati elemen-elemen formal dan struktur desain seperti warna, perspektif, bingkai dan komposisi, penulis menjelaskan cara-cara bagaimana makna berkomunikasi melalui citra. Buku ini dapat menjadi alat penting untuk membaca suatu citra. Melalui buku ini dan menerapkan pada contoh di lingkungan sekitar, dapat dipahami sejumlah teks penting pada desain, komunikasi, media, dan seni.
\end{abstract}

Kata kunci : desain, visual, citra, semiotik, struktur

\begin{abstract}
This article is a book review entitled Reading Images: The Grammar of Visual Design, by Gunther Kress and Theo van Leeuwen, first published in 1996. This book review article using a number of examples of sign systems at Trisakti University, campus A, for an easy understanding. The grammar of visual design plays an equally vital role in the production of meaning. The authors intend to provide inventories of the major compositional structures which have become established as conventions in the course of the visual semiotics. The aim of this book also to analyze how they are used to produce meaning by contemporary image makers. This book provides the first systematic and comprehensive account of the grammar of visual design. Looking at the formal elements and structures of design such as colors, perspectives, framing, and compositions, the authors examine the ways in which images communicate meaning. This book is an invaluable tool kit for reading images. It will be an essential text for anyone interested in design, communication, media and art.
\end{abstract}

Keywords: design, visual, image, semiotic, structure

\section{PENDAHULUAN}

Ketika memasuki suatu habitat, institusi, atau suatu kawasan, maka akan berlaku sistem tanda (sign system) yang dianut oleh lingkungan tersebut. Demikian pula kita memasuki lingkungan perguruan tinggi seperti Universitas Trisakti, kampus Kiai Tapa 1, maka sign system dari kampus harus ditaati dan mudah dipahami oleh seluruh pengunjung. Mencermati tanda-tanda yang terpasang pada suatu lingkungan, akan memudahkan pendatang baru dan dapat menjelaskan tentang citra lingkungan tersebut. Sebaliknya, suatu lingkungan yang tidak memiliki sign system memadai, akan menyesatkan serta memberi citra kurang baik bagi lingkungan bersangkutan. 


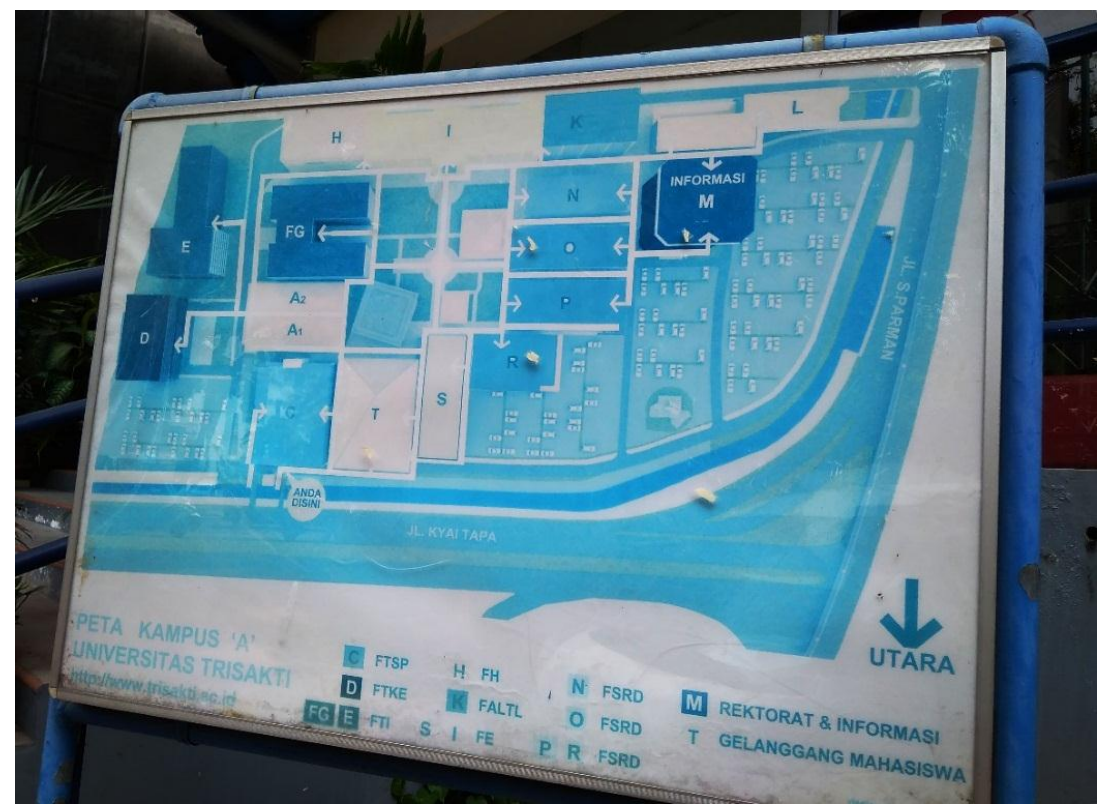

Foto 1. Papan peta kampus A Universitas Trisakti (foto karya: Bambang Tri Wardoyo, 2017)

Impresi pertama memasuki suatu kawasan adalah sarana fisik. Impresi ini sangat penting karena dapat menjelaskan tata kelola hingga citra dari suatu kawasan dan institusi bersangkutan. Termasuk dalam sarana fisik antara lain adalah gerbang masuk, beranda, gedung, taman, hingga sistem tanda (sign system) yang menjelaskan tentang kawasan ter- sebut. Dalam suatu dialog dengan orang tua mahasiswa, seorang ibu menceritakan ia melarang anaknya kuliah di suatu institut karena sarana fisik yang tidak terawat. Citra yang buruk, tidak di-inginkan oleh calon orang tua mahasiswa, sistem tanda yang membingungkan, tata kelola sarana kurang memadai, seakan mewakili seluruh entitas di dalamnya.

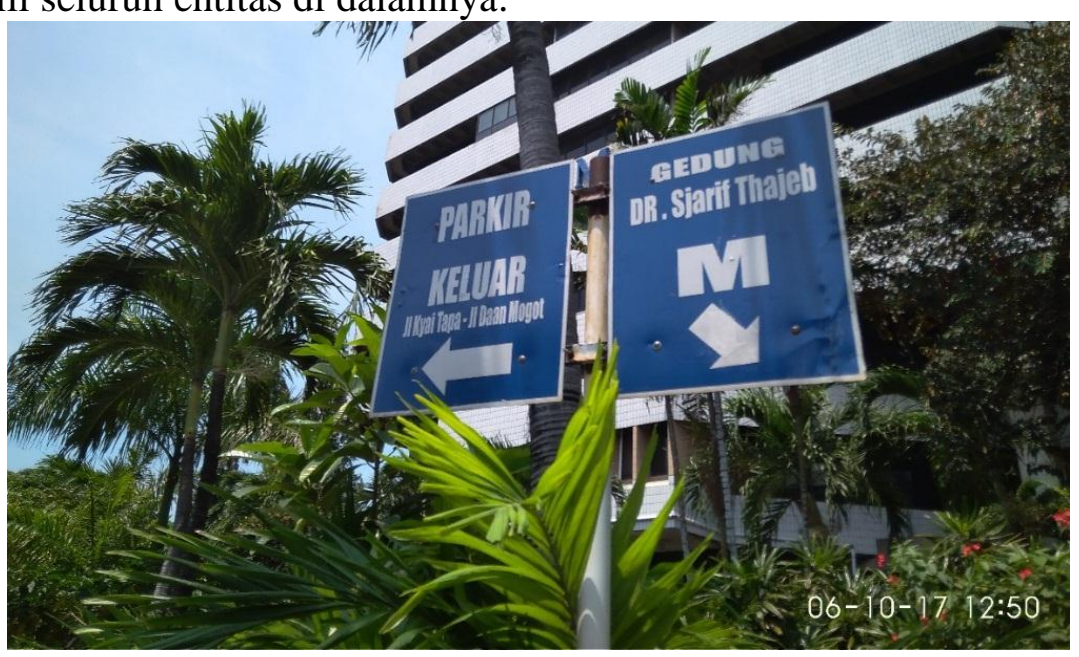

Foto 2. Rambu sign system Kampus A Universitas Trisakti (foto karya: Bambang Tri Wardoyo, 2017)

Perhatikan papan Peta Kampus A Universitas Trisakti (foto 1). Terkait sistem tanda sebagai bentuk interaksi awal bagi pendatang baru di suatu kawasan, dapat dikatakan informasi yang diberikan dapat membingungkan dan multi tafsir. Fungsi utama suatu papan informasi adalah dalam waktu singkat terbatas, seorang pengguna awal dapat mudah memahami dan 
mampu men-jelaskan informasi yang dibutuhkan. Mengutip semiotikus Charles Sanders Peirce (1839-1914), tanda pada papan informasi tersebut dapat dimasukan sebagai sin-sign (suatu tanda karena ketidaklaziman). Peletakan teks Peta Kampus A, selazimnya berada di bagian atas tengah atau bawah tengah dari suatu papan informasi. Demikian pula peletak-an arah Utara yang berada di kanan bawah, termasuk tanda yang tidak biasa. Dalam tingkat pemahaman umum, arah bawah lazimnya merujuk pada arah Selatan. Papan informasi ini secara nalar menimbulkan disorientasi bagi pengguna awal. Tanda yang disajikan juga penuh, padat, rinci, hingga makin mempersulit pemahaman pencari informasi.

Lantas, pertanyaan yang muncul apakah pendekatan semiotik cukup valid untuk membedah suatu tanda visual? Melalui buku "Reading Images: Grammar of Visual Design" karya Gunther Kress dan Theo van Leeuwen (1996), dikaji peran penting dalam produksi makna, dan aspek ini yang penulis cari untuk menjelaskan isi buku. Kedua penulis berusaha menyediakan inventori dalam pendekatan semiotika visual. Buku ini juga menganalisa bagaimana masyarakat menghasilkan makna melalui penciptaan citra kekinian.

\section{METODE PENELITIAN}

Tulisan ini memakai pendekatan deskriptif-kualitatif. Menurut Tjuparmah dan Yooke (2007) pengertian deskriptif adalah "Suatu karya tulis prosa yang subyek karangannya dalam pengertian penglihatan (visual). Suatu karangan yang mencatat atau merekam suatu subyek" (2007: 55). Landasan tulisan ini memakai pendekatan deskripsi adalah obyek yang dikaji dipaparkan menurut fakta-fakta yang ada. Fakta-fakta yang ada berupa dokumentasi terhadap rambu sistem tanda (sign system) di kampus A, Universitas Trisakti, jl. Kiai Tapa 1, Jakarta Barat. Pendekatan deskripsi bertujuan memaparkan kondisi yang ada serta menguraikannya. Konsep deskripsi dapat diterapkan dalam penelitian seni rupa dan desain dengan syarat bahwa topik penelitian menyangkut observasi terhadap obyek yang diteliti (Sumartono, 2018: 13).

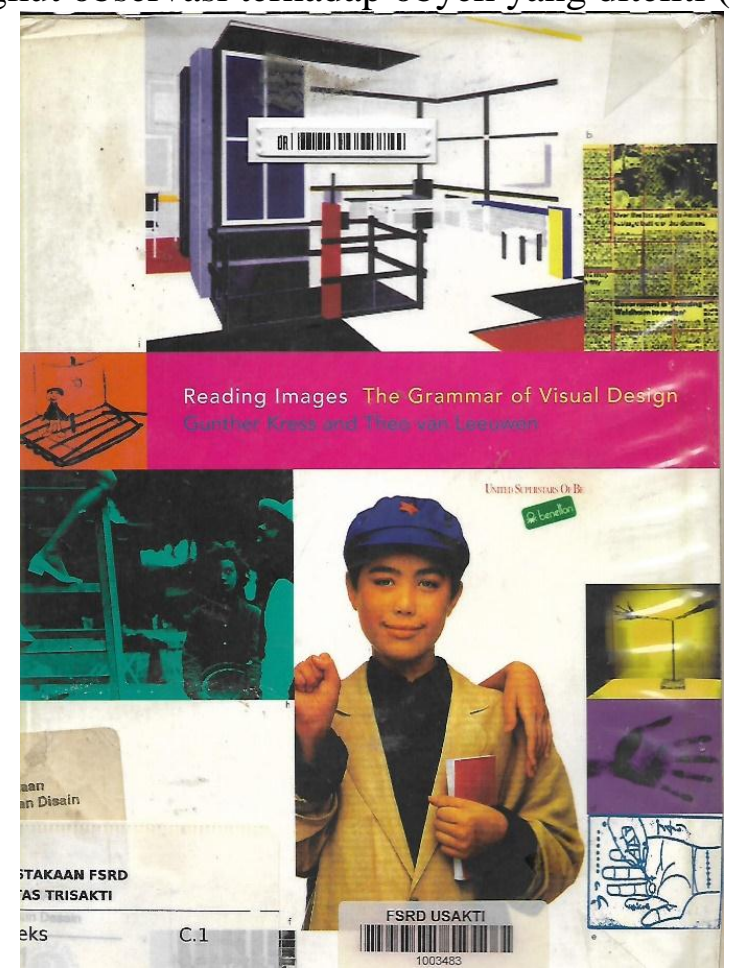

Foto 3. Cover Reading Images: The Grammar of Visual Design (Scan: Bambang Tri Wardoyo, 2017) 


\section{HASIL DAN PEMBAHASAN}

\section{Tanda Visual}

Untuk memahami sistem tanda pada suatu lingkungan, dapat di-pertimbangkan pendekatan visual. Sebagai suatu sistem, idealnya memiliki struktur, tata rupa, atau dalam konteks linguistik, memperhatikan grammar dari desain visualnya. Terkait dengan hal tersebut, buku berjudul "Reading Images: The Grammar of Visual Design" karya Gunther Kress dan Theo van Leeuwen (1996) dapat secara gamblang membantu. Pengertian dari kata grammar dalam buku ini merujuk pada aturan. Melalui aturan ini, kita dapat membedakan antara orang profesional dari orang amatir. Lebih jauh juga menjelaskan perbedaan kajian yang memiliki landasan dan tidak berlandaskan.

Dalam pandangan penulis buku ini, semiotika visual memberi konsentrasi pada aspek bahasa, apa yang disebut sebagai lexis dan grammar sebagai aturan tata bahasa perbendaharaan kata. Contohnya pada kata denotatif dan konotatif, ikonografis dan ikonologis, menjelaskan tentang orang, tempat, dan benda berpadu menjadi sesuatu yang bermakna. Seperti halnya tata bahasa, menjelaskan bagaimana kata-kata berpadu menjadi klausa, kalimat, dan teks, demikian pula halnya dengan tata bahasa visual yang akan menjelaskan kepada masyarakat, tempat, dan benda berpadu menjadi pernyataan visual yang makin besar - kurang terhadap kompleksitas.

Kress dan Leeuwen bukan orang pertama yang menulis tentang obyek ini. Kajian terhadap visual, pemakaian kata denotatif-konotatif, makna simbolik, kajian visual, tata bahasa ditulis dengan cara sistematik. Fokus buku ini pada aspek formal, mendeskripsi imaji estetik, terkadang berdasarkan persepsi psikologi, atau terkadang lebih pada deskripsi pragmatis, sebagai contoh bagaimana komposisi dipergunakan untuk mengundang perhatian pemirsa lebih baik daripada obyek yang lain. Demikian pula sistem tanda (sign sistem) pada kampus A, Universitas Trisakti, dapat dilihat sebagai suatu komposisi. Susunan dari tanda-tanda tersebut sebaik-nya integral satu sama lainnya.

Apa yang disebut sebagai tata visual memang berasal dari tata bahasa linguistik. Tata bahasa secara formal kemudian diterapkan pada bidang visual. Tata bahasa secara umum dipelajari sebagai upaya mengisolasi kata dari makna. Setiap bahasa memiliki standar yang berbeda. Menurut bahasa "Standar orang Eropa", dikenal kata musim semi, musim gugur, musim panas, pagi, siang, sore, malam sebagai kode dari kata benda. Tentu saja kata bahasa itu menjadi mungkin di interpretasikan sebagai waktu, seperti halnya segala sesuatu yang dapat dihitung, dipakai, disimpan, dan seterusnya. Pada suku Hopi, Bahasa Indian Amerika, hal ini sangat tidak mungkin. Dalam konsep suku Indian Hopi, hal ini tidak mungkin. Waktu hanya dapat diekspresikan sebagai"perasaan subyektif terhadap waktu”. Dalam Bahasa suku Hopi, kata "sore", atau "tiga musim semi" tidak dikenal.

Grammar goes beyond formal rules of correctness. It is a means of representing patterns of experience.. It enables human beings to build a mental picture of reality, to make sense of their experience of what goes on around them and inside them. (Halliday, 1985: 101)

Demikian pula halnya dengan grammar of visual design. Buku ini memaparkan secara mendalam dan memberi banyak contoh.

Analogi memakai pendekatan bahasa tidak hanya berdampak, menjelaskan bahwa struktur visual seperti halnya struktur bahasa. Struktur visual menyadari bahwa makna sebagai struktur bahasa juga, dan menjadi titik interpretasi berbeda dari suatu pengalaman dan bentuk berbeda dari suatu interaksi sosial. Makna yang dapat di disadari dalam bahasa dan komunikasi visual saling tumpang tindih dalam berbagai bagian, beberapa bagian dapat di ekspresikan baik secara visual dan verbal. Dalam beberapa bagian keduanya menyatu, beberapa hanya dapat 
dilakukan secara visual, sebagian lain hanya dapat secara verbal. Akan tetapi walaupun sesuatu dapat dilakukan secara visual maupun verbal, keduanya adalah berbeda. Sebagai contoh: apa yang diekspresikan dalam bahasa melalui pilihan antara kelas kata berbeda dan struktur semantik, ekspresi komunikasi visual terwujud melalui warna juga penggunaan struktur komposisi yang berbeda.

\section{Memahami Grammar}

Grammar diartikan sebagai sekumpulan aturan-aturan yang harus diikuti jika kita ingin berbicara atau menulis secara benar. Agar dapat diterima secara sosial, para komunikan dituntut berbicara dengan runtut dan benar. Demikian pula dengan bahasa visual, harus ditempatkan pada tempat dan susunan yang mudah dipahami bagi siapapun penggunanya. Grammar melibatkan pengetahuan yang ber-transformasi dari deskriptif ke normatif. Maka ketika sistem tanda (sign system) berupa susunan warna, garis, komposisi petunjuk yang deskriptif, kemudian juga menjelaskan norma-norma yang dianut oleh lingkungan tersebut.

Semiotika memainkan peranan peran dominan dalam komunikasi publik, termasuk sistem tanda (sign system). Namun dalam perjalanannya, grammar seringkali terhalangi oleh sejumlah aturan-aturan. Sebagai contoh tentang aturan yang tertulis dan tidak tertulis. Serta terdapat segelintir kalangan elit yang diizinkan untuk mendobraknya. Kress-Leeuwen meyakini bahwa komunikasi visual menjadi meningkat pada domain spesialis, dan menjadi semakin berkurang pentingnya pada domain publik. Tidak memahami literasi visual akan mengundang sanksi sosial dari masyarakat. Literasi visual dalam membaca sistem tanda (sign system). kemudian sangat krusial khususnya di tempat kerja seperti kampus A, Universitas Trisakti.

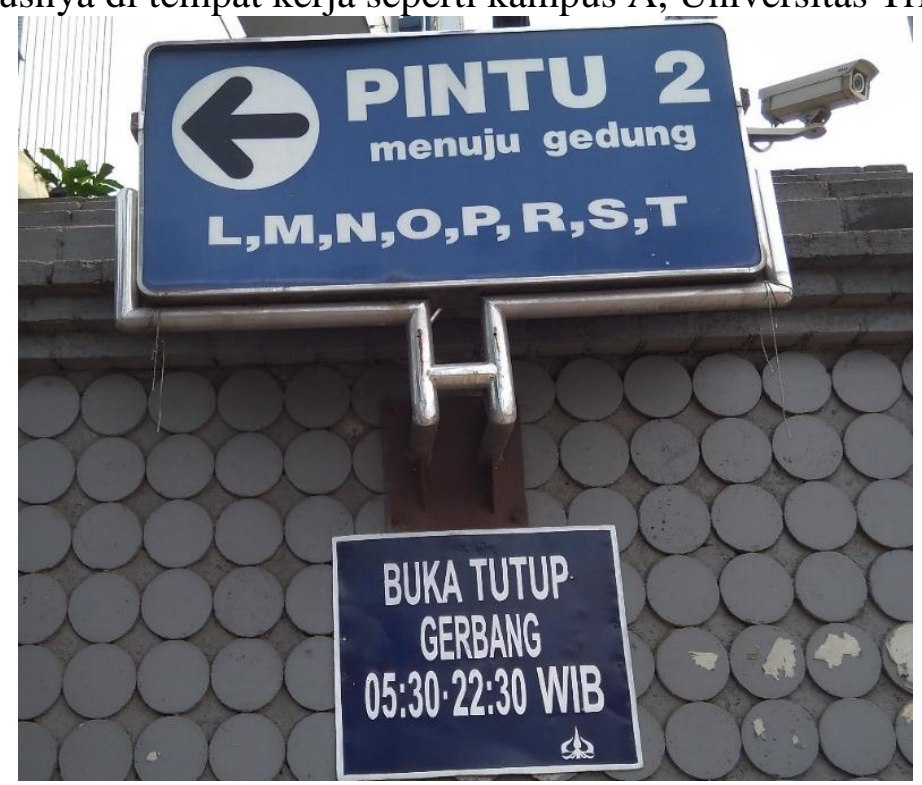

Foto 4. Papan informasi penunjuk gedung Trisakti (foto karya: Bambang Tri Wardoyo, 2017)

Mengajarkan aturan-aturan menulis, tidak berarti menjadi akhir dari kreatifitas dari berbahasa dan bidang lainnya. Ketrampilan mengajar visual tidak berarti menjadi akhir dari kreatifitas dalam seni. Demikian pula halnya terhadap grammar yang secara kreatif dipakai oleh para puisiwan, novelis, dan sastrawan, pada akhirnya serupa ketika kita menulis memo, surat, laporan, demikian pula halnya dengan "Grammar of Visual Design” yang secara kreatif dikerjakan oleh para seniman, desainer, dan pada akhirnya grammar yang sama untuk menciptakan layout, citra, diagram, termasuk buku kuliah, laporan, brosur, dan sebagainya. 
Penting untuk mempertanyakan di sini, apakah grammar bahasa adalah sama dengan grammar yang lainnya? Jawaban yang biasa diberikan adalah bahwa grammar Bahasa Inggris, Perancis, Belanda memiliki kekhasan masing-masing. Jawaban yang memadai adalah bahwa grammar adalah suatu susunan dari elemen-elemen dan aturan-aturan yang berdasarkan budaya komunikasi verbal yang spesifik. Lantas, apakah grammar visual juga merupakan grammar? Dapat dikatakan oleh penulis, bahwa diperlukan kata grammar untuk memudahkan pemahaman dalam buku ini. Diperlukan kata yang dapat me-wadahi dari karya seni lukis hingga layout majalah, komik, sebagai karya ilmiah. Dapat dikatakan bahwa grammar dari desain visual merupakan sebuah karya dari budaya Barat. Menurut Kress dan Leeuwen sistem komunikasi memiliki sejarah, tumbuh, lebih dari lima abad lamanya. Batasan-batasan tersebut bukan hasil dari aturan negara (walaupun terkadang negara juga terlibat, dalam berbagai variasi daerah setempat). Maka dapat dikatakan bahwa budaya Barat kemudian menjadi suatu budaya yang dominan.

Hal ini berarti bahwa tidak ada grammar yang berlaku universal. Bahasa visual tidak bersifat transparan dan dapat dipahami secara universal, akan tetapi lebih ditaati khusus budaya penganutnya. Penulis berharap buku ini dapat menyediakan beberapa ide dan konsep untuk komunikasi pada bentuk komunikasi visual budaya non Barat. Untuk memberi contoh yang sangat jelas, komunikasi visual Barat sangat di-pengaruhi oleh kesepakatan menulis dari kiri ke kanan. Pada budaya lain, Cina misalnya, dari atas ke bawah. Dan konsekuensi menghasilkan nilai-nilai berbeda dan maknanya terhadap dimensi kunci ruang visual. Berbagai penilaian dan makna digunakan untuk mem-pengaruhi melampaui tulisan, dan memberikan makna berdasarkan pola-pola komposisi berbeda, jumlah untuk membuatnya dan seterusnya. Dengan kata lain, penulis berpendapat bahwa elemen-elemen seperti 'centre', 'margin', 'top' atau 'bottom', elemen-elemen yang dipakai pada semiotika visual dari berbagai budaya dan nilainilai yang sepertinya berasal dari budaya Barat. Penulis berpusat pada isu ini dari waktu ke waktu. Penulis lebih memilih untuk menandai bahwa investigasi sangat terbatas, dalam skala luas, untuk komunikasi visual Barat. Dalam budaya visual Barat, barangkali penulis meyakini bahwa teori yang diterapkan pada semua bentuk komunikasi visual. Penulis berharap bahwa berbagai contoh luas yang dipakai dalam buku ini dapat meyakini dalil-dalilnya.

Kedua penulis meyakini bahwa desain visual, seperti halnya bahasa, juga semua mode semiotika bertujuan dua fungsi utama. Memakai pendapat Halliday, semiotika bertujuan antara fungsi ideasional, sebuah fungsi yang mewakili 'dunia sekitar dan apa yang ada di dalam kita', dan sebuah fungsi interpersonal. Suatu fungsi yang mem-buat interaksi sosial sebagai suatu relasi sosial. Apakah kita terlibat dalam suatu pembicaraan, membuat iklan atau memainkan musik, manusia melakukan komunikasi berkesinambungan sebagai suatu konteks sosial, dan representasi beberapa aspek dunia di luar dirinya. Demikian pula saat mengkaji sistem tanda pada perguruan tinggi seperti contoh di atas.

Struktur dari buku Grammar of Visual Design menjelaskan hal ini. Bab 2 dan 3 berhubungan dengan pola-pola representasi dimana grammar visual desain menjadi tersedia dan karenanya kita dapat melakukan kode pengalaman secara visual. Bab 4 dan 5 berisikan pola-pola interaksi dimana grammar visual desain menjadi tersedia, dan tentu saja dengan segala sesuatu yang kita dapat lakukan untuk satu sama lain dengan komunikasi visual, dan hubungan antara pembuat dengan pemirsa tanda visual menjadi berarti. Bab 6 berhubungan dengan apa yang Halliday sebut sebagai fungsi tekstual, dengan cara representasi dan tindakan komunikatif bersatu menjadi sesuatu yang bermakna. 


\section{SIMPULAN}

Terhitung cukup banyak buku yang menulis tentang semiotika. Setiap buku dapat memakai perspektif yang berbeda-beda. Namun terpenting juga bagaimana suatu perspektif buku dapat diterapkan pada obyek tertentu, dalam hal ini sistem tanda (sign system) yang ada di lingkungan sekitar. Semiotika dapat dianalogikan sebagai pisau bedah yang dapat dipakai untuk membedah obyek tertentu, dalam tulisan ini adalah sistem tanda di perguruan tinggi. Memakai pendekatan ini, setiap mahasiswa dapat lebih kritis dan analitis dalam melihat fenomena di sekitarnya.

Sistem tanda (sign system) kampus A, Universitas Trisakti, setelah dikaji melalui perspektif Kress-Leeuwen menjelaskan elemen-elemen formal dan struktur desain seperti warna, perspektif, bingkai dan komposisi yang idealnya integral. Bahasa visual dituntut untuk dapat dipahami secara universal, serta ditaati khusus lingkungan budaya penganutnya. Ketika sistem tanda (sign system) suatu lingkungan tertata dengan baik dan terpadu, maka kemudian dapat meningkatkan citra dari lingkungan tersebut lebih baik. Hal ini juga dapat berlaku pada perguruan tinggi lainnya.

\section{DAFTAR PUSTAKA}

Halliday, M.A.K. (1985). An Introduction to Functional Grammar, Edward Arnold, London

Kress, Gunther, van Leeuwen, (1996). Reading Images : The Grammar of Visual Design, Routledge, London

Komaruddin, Tjuparmah, Yooke. (2007). Kamus Istilah Karya Tulis Ilmiah, penerbit Bumi Aksara, Jakarta

Sumartono. (2017). Metodologi Penelitian Kualitatif Seni Rupa dan Desain. Pusat Studi Reka Rancang Visual dan Lingkungan, Fakultas Seni Rupa dan Desain, Universitas Trisakti, Jakarta

Watson, J, Hill, A, (1980. A Dictionary of Communication and Media Studies, Edward Arnold, London 